\title{
Effects of Internal and External Factors on Profitability of Jordanian Commercial Banks: Panel Data Approach
}

\author{
Hussain A. Bekhet ${ }^{1}$, Ahmad Mohammad Alsmadi ${ }^{1}$ \& Mohamed Khudari $^{1}$ \\ ${ }^{1}$ College of Graduate Studies, Universiti Tenaga Nasional, Kajang, Malaysia \\ Correspondence: Hussain A. Bekhet, College of Graduate Studies, Universiti Tenaga Nasional, 43000 Kajang, \\ Selangor, Malaysia. E-mail: drbekhet1953@hotmail.com
}

Received: June 25, 2020

Accepted: August 9, 2020

Online Published: October 4, 2020

doi:10.5430/ijfr.v11n5p359

URL: https://doi.org/10.5430/ijfr.v11n5p359

\begin{abstract}
This article assesses the effects of internal and external factors on the profitability of Jordanian commercial banks. A panel data set of thirteen commercial banks between 2000 and 2018 was used. Pooled ordinary least squares, random and fixed models were applied. Moreover, a Hausman test was performed to confirm the suitability of models, which was preferred on the random effect model. Also, a Wooldridge test for serial correlation and a modified Wald test for groupwise Heteroskedasticity were used and both of their null hypotheses were rejected. However, to deal with these problems, a robustness analysis was performed using feasible generalized least square. The findings suggested that internal factors and in particular, bank size and diversification, had positive effects on bank profitability, while credit risk, operational risk and leverage risk were negatively related to bank performance. However, capital risk had a positive but insignificant impact on bank profitability. As for the effect of external factors, the results suggested that financial development and inflation had a positive and significant impact on bank profitability, while market concentration and stock market volatility had a significant negative effect on bank profitability. Further, a negative and insignificant impact were found for GDP and refugee crisis on bank profitability in Jordan. The findings would help managers of commercial banks, investors, government, policy makers and shareholders to make better decisions and improve performance by highlighting areas of weaknesses. In general, policy makers should become more aware with these insights on profit determinants in Jordanian commercial banks.
\end{abstract}

Keywords: bank profitability, commercial banks, fixed and random effects, refugee crises, Jordan

JEL Classification: C33, F43, G14, G21, G32

\section{Introduction}

Over the past decades, it was argued that the stability and profitability of banks is a growing concern of policy makers, regulators and bank supervisors. However, such concerns gained importance after the world financial crises of 2007/2008 (Ali \& Puah, 2018). The economy of any country depends heavily on the performance of its banking sector. Banks play an increasingly vital role in the growth and economic development of any economy (Almaqtari, Al-Homaidi, Tabash, \& Farhan, 2019). A profitable and efficient banking sector acts as a catalyst for economic growth. The 2007/2008 financial crisis showed it is important to understand the risks and how they impact financial operations of different financial institutions (Bekhet \& Yasmin, 2014). Furthermore, a solid and profitable banking system enhances economic stability and efficiency to mitigate effects of any sudden macroeconomic shocks. To be more efficient and profitable, banks need to know which types of factors have a greater effect on their performance. Moreover, it is recognized that policymakers also need to know the risks faced by banks to effectively regulate them. The studies on internal and external factors affecting bank profitability have grown rapidly, especially those concentrating on developed country economies (Iskandar, Che-Yahya \& Wahid, 2019; Öhman \& Yazdanfar, 2018; Fidanoski et al., 2018; Bongini et al., 2018; Garcia \& Guerreiro, 2016). However, according to Ariyadasa, Selvanathan, Siddique \& Selvanathan, (2017) not many studies have been conducted on developing countries and one of these countries is Jordan.

In Jordan, the financial system has played an important role in enhancing the country's economic development in past years. The banking sector in Jordan, being the biggest component in the financial sector, forms around $93.3 \%$ of financial system assets (Central Bank of Jordan [CBJ], 2018). The effective role of the banking system played as a major motivation of economic growth, contributing around $24.2 \%$ of the country's GDP along with the insurance and real estate sectors (CBJ, 2018). However, a healthy banking sector not only drives the economic growth; it also facilitates economic activity and helps money policy to be more efficient by stabilizing the country's financial system. In lights of the turmoil of the last few years, the economy is struggling with slow GDP growth and huge 
government debt threatening the economy (Bekhet \& Al-Smadi, 2017). In 2018, government debt reached 94.23\% of the country's GDP (CBJ, 2018). As previously noted, banks are vital to economic growth and stability; therefore, assessment of bank performance is critical to all economic parties: regulators, depositors and bank managers. This importance is derived from the reality that bank performance gives a clear indication to bank managers to improve the lending or deposit services or both of them. In addition, evaluating performance helps investors to decide whether to invest more or to withdraw their investments. Also, it helps the regulator to formulate suitable regulations. Also, Misra (2015) stressed that it is essential for a bank's management to know the reasons for profit variation between one bank and another. In general, the profit was decreased from $1.7 \%$ at the end of 2006 to $1.2 \%$ at the end of 2018 (CBJ, 2018).

In addition, bank management needs to know the reasons behind profitability decline to manage the key controllable factors properly and to maximize the bank's profits, which will finally lead to more stability in the whole economy. However, this study was aimed to provide a better understanding of the factors affecting commercial bank profitability in Jordan by highlighting the effect of the refugee crises period on profits during the Arab spring years. Therefore, this article discusses the following study objectives:

- To determine the impact of banks' internal factors (credit risk, liquidity risk, leverage risk, operational risk, capital risk, bank size and diversification) on Jordanian commercial banks' profitability.

- To identify the effects of banks' external factors (market concentration, financial market development, stock market volatility, inflation and GDP) on Jordanian commercial banks' profitability.

- To assess the impact of the refugee crises effect on Jordanian commercial banks' profitability.

To discuss achieving these objectives, this article is structured as follows: Section 2 presents an overview of the Jordanian banking sector. Section 3 discusses the past studies. Section 4 describes the data sources, variables definitions and research methodology. Section 5 deals with empirical results discussion. Conclusions and policy implications are discussed in section 6.

\section{Overview of Jordanian Banking Sector}

The banking sector in Jordan is a key contributor to economic growth. In 2016, along with the insurance and real estate sectors, it accounted for $24.2 \%$ of the country's GDP (CBJ, 2016). Moreover, it is considered the biggest employer in the Jordanian private sector (Awraq Investment, 2015). In 2018, the banking sector consisted of 25 banks: 9 of them were foreign banks' branches and the other 16 were local banks, including 3 Islamic and 13 conventional banks. However, the banking network in Jordan operated through 805 branches and 86 offices, which made the percentage of the population to bank branches ratio about 12.1 thousand citizens per branch (CBJ, 2018).

However, the Jordanian banking sector is considered large relative to the country's size of the economy and when compared with other sectors in the region. In 2018, total assets of the licensed banks in Jordan reached JD48.6 billion, over $161.9 \%$ of the GDP. In comparison, this percentage in UAE and Kuwait was $227 \%$ and $175 \%$ respectively (CBJ, 2018). Figure 1 shows the time trend of total licensed bank assets to GDP ratio (TAGDP) from 1980 to 2018 . In general, it reveals that this relationship grew with an average growth rate of $1.6 \%$ per year. Also, it reveals that the percentage has taken a downward trend for the last 11 years. In 2005, this ratio reached its peak at 236\% of the GDP. Then, it dropped down dramatically to $161.9 \%$ at the end of 2018 . This decrease is attributed to faster growth in the GDP over the growth in banking assets.

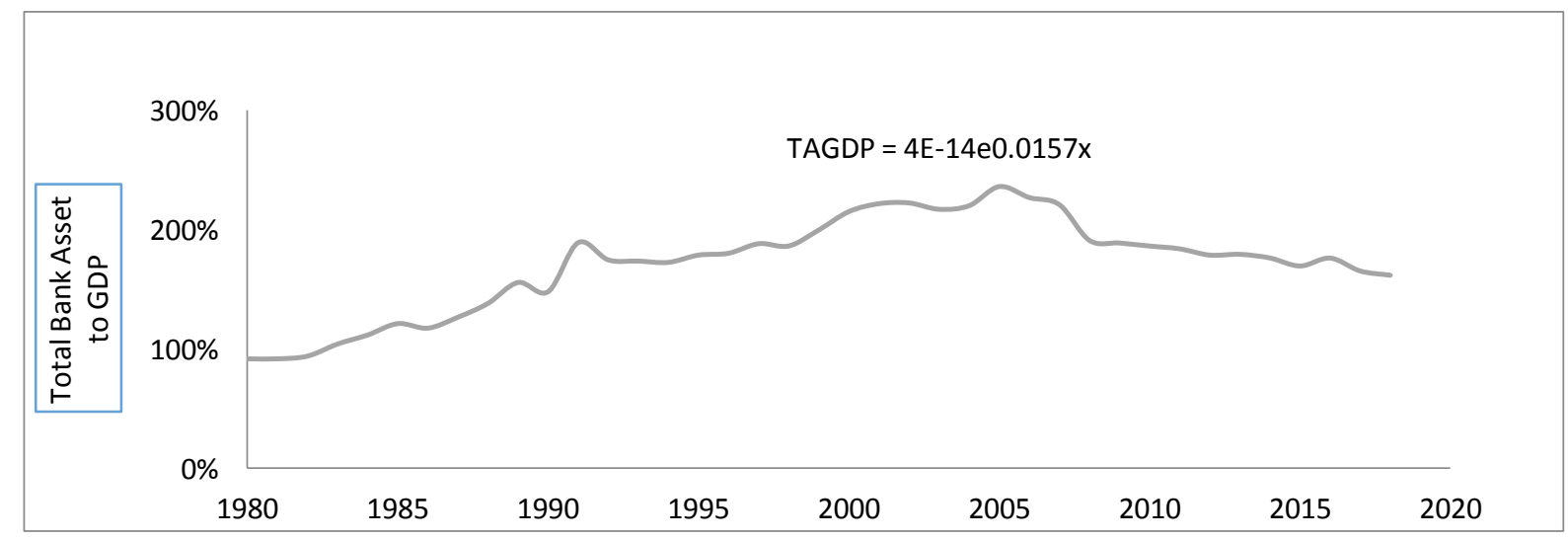

Figure 1. Time trend of total bank assets to GDP (\%) from 1980 to 2018

Source: IMF (2018). 
Therefore, according to Bekhet \& Eletter (2012), the banking sector in Jordan has been a major supporter of various economic activities and contributed significantly to social development. In 2018, the biggest portfolio in the banking sector was credit facilities, forming $51.3 \%$ of the total assets of the banks. Moreover, it is worth noting that the percentage of credit facilities to GDP in 2018 reached 85.6\% (CBJ, 2018). Figure 2 shows the trend of the total extended credit facilities (TCF) by banks from 1980 to 2018. On average, it reveals that this relationship grew with an average growth rate of $9.5 \%$ per year.

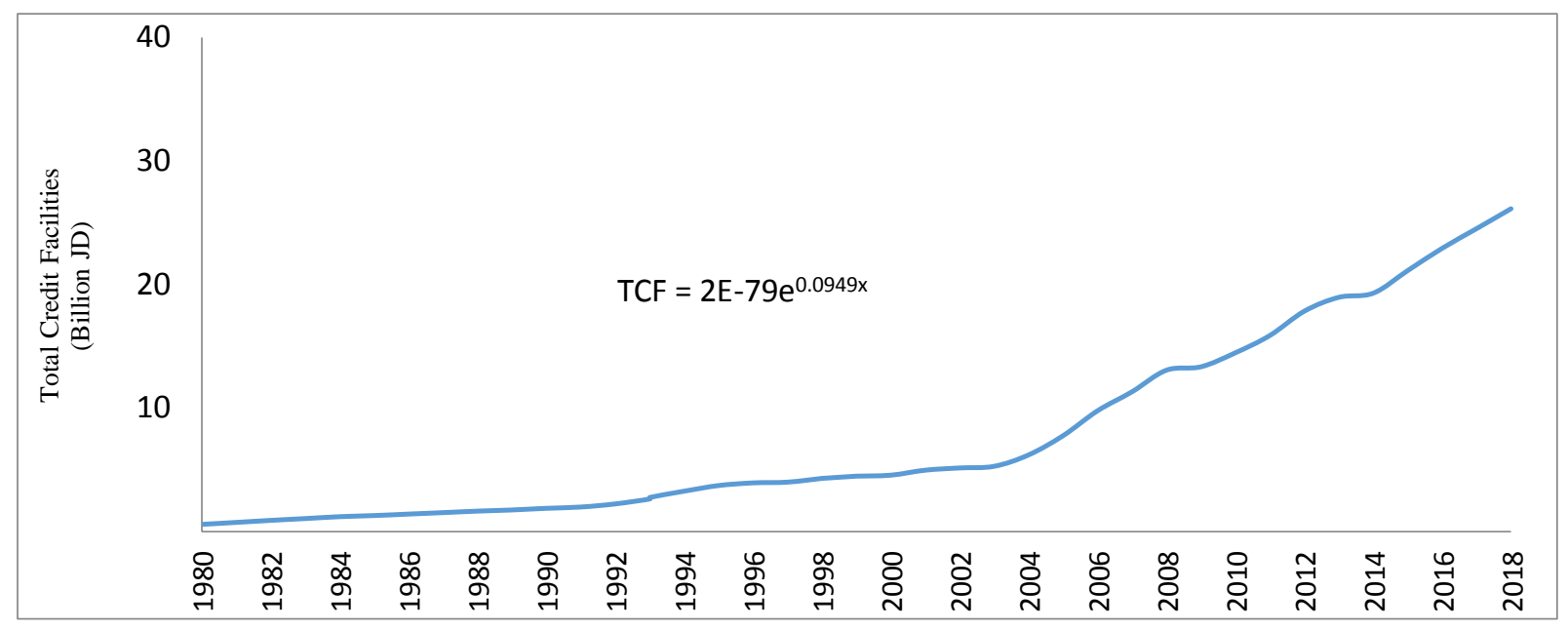

Figure 2. Total credit facilities provided by banks in Jordan from 1980 to 2017.

Source: CBJ (2019)

Furthermore, to highlight the importance of banking to Jordanian economic sectors, Figure 3 shows the spread of banks' credit facilities from 1993 to 2018. It also indicates that most of the credit facilities were provided to the general trade, construction and industry sectors with $13 \%, 21 \%$ and $21 \%$ shares, respectively.

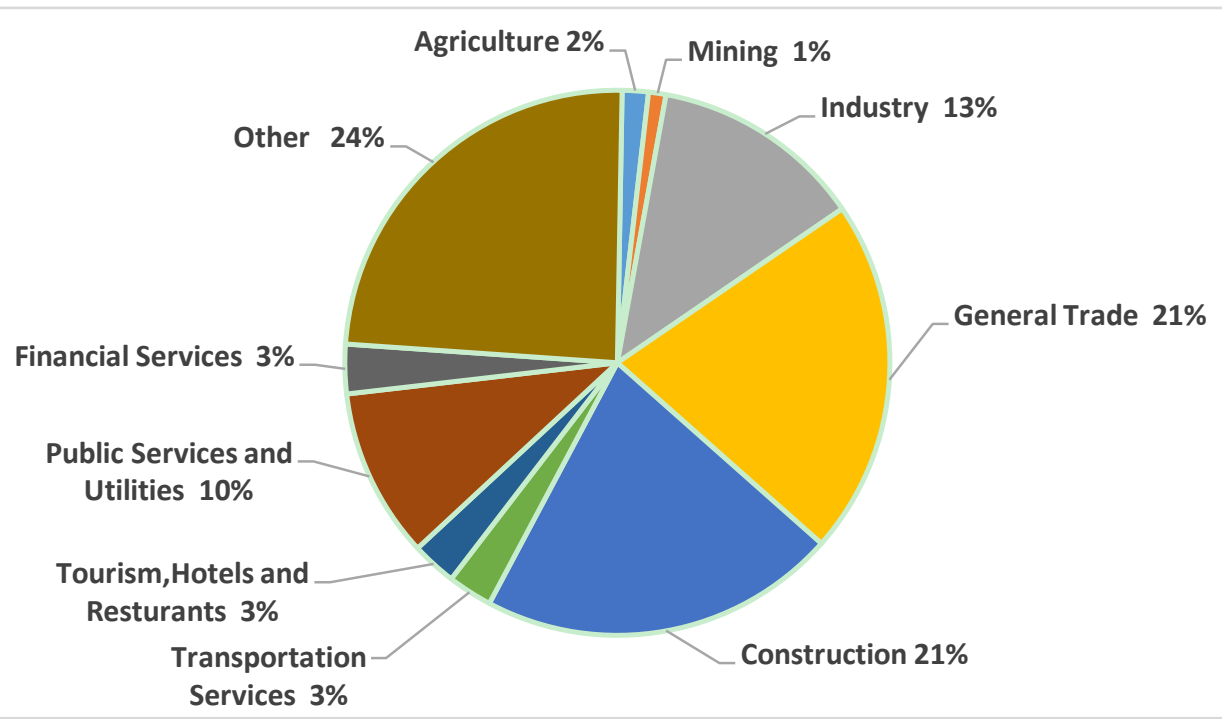

Figure 3. Average credit facilities distribution to Jordanian economic sectors from 1993 to 2018.

Source: CBJ (2019) statistical database, available online at: http://statisticaldb.cbj.gov.jo. 
Following the global 2007/2008 financial crisis, the MENA region showed a significant improvement in its economy as oil prices increased sharply. The IMF (2010) predicted the improvement of the MENA region outlook and that this improvement would contribute to returning to higher economic growth. However, people in the MENA region started a rebellion against their rulers and political regimes. The political conflict interrupted the predicted growth and decreased the profitability of the financial sector. In addition, reflecting their high political risk, Standard \& Poor's lowered its rating of 5 economies in the MENA region. This lowering came as a result of decayed investors' confidence, expansion of spread and aggravation of the present weaknesses (Ghosh, 2016).

During the last two decades, Jordan suffered from the consequences of many regional conflicts (Bekhet \& Matar, 2013). For example, the civil war in Syria caused a flood of refugees migrating to the northern side of the country. At the beginning, such results served as a reminder to the Jordanian people of the revolution's consequences and contributed to calming the situation in Jordan. Unluckily, the war in Syria kept worsening and the number of refugees in Jordan swelled, which caused the population to increase sharply. That increase revealed the vulnerability and weaknesses of the Jordanian economic and social infrastructure (Francis, 2015).

In addition, according to Rother et al. (2016) the conflict in Syria and Iraq slowed GDP growth and accelerated inflation in the MENA region. Precisely, the results revealed that the GDP decreased on average by 2 percentage points in all countries, and by 1.5 percentage points in MENA countries. Meanwhile, in Jordan, the GDP slowed down by 1 percentage point in 2013 and inflation accelerated to 4.6\% in 2014. Furthermore, the increase in inflation despite the slowed economic growth was driven by rental prices, which reflected the increased demand caused by the large refugee population.

\section{Literature Review}

Factors affecting bank performance received considerable attention in recent literature. For instance, many researchers studied the effect of internal and external factors on bank profitability (e.g., Jara-Bertin et al., 2014; Ahmad et al., 2016; Bucevska and Misheva, 2017; Ozili, 2017; Mokni and Rachdi, 2014). This study classified these prior studies into two groups within different models used: those done on multiple economies and those made on individual economies.

First, on a panel of countries, the generalized method of moments (GMM) was employed by many researchers. Dq \& Ngo (2020) examined factors affecting bank profitability in 23 countries. Spanning 2002 to 2016 periods the results indicated that bank profitability is positively related to number of bank cards issued, number of automated teller machines (ATMs), number of point of sales (POS), and capital market development, while negatively related to market power. Jara-Bertin et al. (2014) studied the performance determinants of an unbalanced panel data of 78 Latin American banks from 1995 to 2010. The results showed a positive impact by bank concentration, financial crisis, diversification, capital risk, bank size, inflation and GDP; and negative impact by credit, liquidity and operational risk. A similar study (Saona, 2016) investigated 156 banks from 1995 to 2012 and found a positive impact by capital ratio, diversification, bank size and liquidity risk. A negative impact was detected for financial development and law enforcement. Ahmad et al. (2016) also studied profitability determinants of Latin American banks along with East Asian ones. They used unbalanced panel data of 156 banks from 2003 to 2014. The results emphasized the positive impact of capital adequacy, bank size and market concentration on East Asian bank profits. Meanwhile, it was negatively impacted by efficiency and liquidity risk. However, no significant effect was found for credit risk, GDP and inflation. In case of Latin American banks, profitability was found to be impacted positively by GDP, inflation and market concentration, while affected negatively by operational risk. In Europe, Bucevska and Misheva (2017) investigated bank performance in the Balkan region using an unbalanced panel data of 127 commercial banks from selected Balkan countries from 2005 to 2009. The results showed a positive impact of efficiency and capital and negative impact from credit risk and European Bank for Reconstruction and Development (EBRD) index. However, no significant impact was found for size, market concentration and GDP. Ercegovac, Klinac, \& Zdrilić (2020) investigated bank profitability determinants in European Union using GMM on 22 banks over 2007 to 2019 periods. The outcomes indicated that profitability is determined only by non-performing loan ratio and cost to income ratio and their impact was negative. In Africa, Ozili (2017) examined the banks' profitability determinants of 200 banks from 18 African countries. The results recorded a positive impact by liquidity and capital risk and a negative impact by bank size and credit risk. In the MENA region, Mokni and Rachdi (2014) studied the profitability of 15 conventional banks from 2002 to 2009. The results indicated a positive impact for diversification, capital risk, and GDP and a negative impact was noted for credit and operation risk.

However, in the same context (i.e. panel of countries), other studies used a fixed effect model (FEM) as an estimation method. Sufian (2012) studied bank profitability determinants using unbalanced panel data of 77 banks 
taken from Bangladesh, Sri Lanka and Pakistan from 1997 to 2008. The findings revealed that performance was positively related to credit risk, diversification, liquidity, capitalization, private investments and GDP. However, the results showed a negative impact from cost and private consumption variables. In Europe, Petria et al. (2015) investigated the profitability determinants using panel data of 1,098 banks from EU27 countries from 2004 to 2011. The results recorded a negative impact of management efficiency, credit risk, liquidity risk, market concentration, business mix factor and GDP. Whereas, capital adequacy impacted the return on equity (ROE) negatively and return on assets (ROA) positively. However, inflation didn't have any significant effect. Paolucci (2016) examined the determinants of European banks profitability employing an unbalanced panel data of 35 banks from 2009 to 2013. The results stressed positive effects of capital risk, deposits to total assets and bank size. Also, a negative significant impact of credit risk on bank profitability was noted along with no impact at all for the liquidity risk factor.

Furthermore, some other researchers used an ordinary least squares (OLS) estimator. In Europe, Bogdan and Ihnatov (2014) studied bank profitability using OLS analysis on a data set of 143 commercial banks from Romania, Hungary, Poland, Czech Republic and Bulgaria from 2004 to 2011 . The study indicated that profitability was positively related to bank size, capital adequacy ratio, efficiency, GDP and inflation. However, it also stressed that bank profitability was negatively related to credit risk and off balance sheet. Titko et al. (2015) used OLS analysis on 43 banks and financial institutions in Latvia and Lithuania. They found that profitability was positively affected by credit risk and operational risk while negatively affected by liquidity risk. Bongini et al. (2018) tested the determinants of profitability shocks and recovery in the European banking sector. Their study employed univariate analysis on a sample of 109 banks holding companies spanning 2006 to 2016. The findings indicated that the profitability deterioration was caused by credit risk and capitalization.

Second, in the group of individual economies, the generalized method of moments (GMM) was also used by many researchers. Marijana et al. (2012) examined the profitability determinants in Macedonia using a panel data of 16 banks from 2005 to 2010. The findings showed a positive impact of GDP, EBRD and market concentration. Meanwhile, a negative impact of capital risk, liquidity risk and operating expense was recorded. However, no impact of credit risk, bank size and fees income were noted. Furthermore, Pervan et al. (2015) studied the Croatian banks' profitability determinants using a panel data of 46 Croatian banks from 2002 to 2010. The results concluded a positive influence by industry concentration, lagged profitability, intermediation, bank size, capital risk, GDP and market growth. However, a negative influence was revealed for operating expenses management, credit risk and inflation. In Asia, Al-Homaidi et al., (2018) studied the determinants of 69 Indian banks using regression and GMM for 2008 to 2017. The results showed the profitability measured by ROA was affected positively by size, asset management, inflation and number of branches, while negatively affected by interest rate, GDP, and exchange rate. However, when measured by ROE, it was positively affected by credit risk, liquidity risk, asset management and GDP. A negative association was exhibited for exchange rate, operating efficiency, inflation rate, interest rate, number of branches and leverage. Tan \& Floros, (2012) investigated the profitability determinants of the Chinese banking sector using an unbalanced panel data of 101 banks from 2003 to 2009. Their findings indicated that profitability was positively related to cost efficiency, concentration, banking sector development and stock market development. It was negatively related to taxation and GDP growth. Furthermore, the results also showed that ROA was also positively impacted by capitalization, credit risk and labor productivity. In Africa, Bougatef (2017) examined profitability in Tunisian banks and its relation to corruption. He used a panel data set of 11 commercial banks from 2003 to 2014. The results found that profitability was positively related to corruption, liquidity risk, capitalization, size and cost to income ratio. However, with regards to credit risk, the impact was negative and was significant when measured by only ROA.

Many other studies used a fixed effect model (FEM) when considering a single economy. In Asia, Jadah, Alghanimi, Al-Dahaan, \& Al-Husainy (2020), studied the impact of internal and external factors on profitability of 18 Iraqi conventional banks spanning 2005 to 2017 periods. Using FEM, the results recorded that profitability of Iraqi banks is positively related to, equity to total assets, total loans to total assets ratios, bank size ,GDP growth, and government effectiveness. Meanwhile, inflation, credit risk, and political instability had a negative impact on bank profitability. Batten and Vo (2019) examined the impact of bank specific, market specific and macroeconomic variables on the profitability of 35 Vietnamese banks from 2006 to 2014. The results recorded a negative impact by size, operational risk and market concentration and a positive impact by capital ratio, productivity and inflation. Meanwhile, no impact was noted by credit risk, inflation and GDP. In Indonesia, Hasan, Manurung, \& Usman (2020) studied the determinant of Indonesian banks profitability using FEM on 26 banks for 2007 to 2018 period. The results indicated that capital adequacy ratio and operational cost to revenue are negatively related to bank profitability, while net interest margin, loan to deposit ratio, FED rate, and consumption of Cement are positively 
related to bank profitability. Another research conducted by Also, Arafat et al. (2013) studied the bank profitability determinants using an unbalanced panel data of 25 banks from 2005 to 2007. The findings showed a positive relation to size and assets growth rate and a negative one to credit risk. However, with regards to net interest income to total assets variable, the study found that it was negatively related to growth rate and bank size while positively related to credit risk. In addition, a study by Ruziqa (2013) examined the impact of credit and liquidity risk on conventional Indonesian banks using FEM on a panel data of 23 conventional banks from 2007 to 2011. It concluded that higher profitability was associated with higher bank capital and lower credit and liquidity risk. Misra (2015) examined the profitability determinants in Indian banks using a panel data of 127 Indian banks from 2000 to 2011. The results indicated that ROA was positively affected by diversification, size, capital adequacy and net interest margin (NIM) and was negatively affected by liquidity and credit risk. However, ROE was found to be positively affected by diversification and NIM. Furthermore, no evidence was found of any effect for liquidity, deposits to total assets, GDP, inflation and real interest rate on bank profitability. In UAE, Chowdhury (2015) studied the determinants of profitability and operating efficiency of banking industry using unbalanced panel data of 23 banks from 1992 to 2010. The results showed that profitability was positively related to capital ratio and lagged profitability and was negatively related to credit risk and bank size.

In Europe, Garcia and Guerreiro (2016) studied the internal and external determinants of bank profitability in Portugal. Their study used unbalanced panel data of 27 Portuguese banks over two study periods, 2002 to 2011 and 2008 to 2011, to capture the differential effect of the financial crisis. For the two periods, the results showed that profitability was negatively related to cost to income ratio and real growth of GDP, while positively related to the difference between bank and market growth of total loans and the yearly growth of household disposable income. Meanwhile, other variables showed different results among the two periods. The impact of equity to total assets, credit risk and the term structure of interest rates was negative in the first period and positive in the crisis period. However, the impact of the yearly deposit growth was positive for the first period and negative in the crisis period. Knezevic and Dobromirov (2016) tested the impact of bank specific, market specific and macroeconomic variables on the profitability of the Serbian bank industry. They used FEM on panel data of 29 Serbian banks from 2004 to 2011. The results found a negative impact of bank size, operational risk, liquidity risk, market capitalization to total assets and total assets to GDP on profitability. Meanwhile, a positive impact was found for market concentration and market capitalization to GDP. However, the study found no hard evidence that profitability was related to GDP and inflation.

In Africa, Amin et al. (2014) evaluated the relationship between performance and financial risk for 21 Tanzanian banks from 2003 to 2012. The results found that ROA was positively related to real interest rate and negatively related to off-balance sheet activities. Meanwhile, ROE was negatively related to inflation and positively related to real interest rate and off-balance sheet activities. Furthermore, the study found an inverse relationship between risk and performance. Adusei (2015) examined the profitability determinants of the Ghanaian banking sector. The study used panel data of 112 rural banks from 2009 to 2013. The results stressed that bank profitability was positively related to bank size, stability and diversification, while negatively related to funding risk. Meanwhile, the impact of liquidity risk was positive and significant in the case of ROE only. In Morocco, Ferrouhi (2014) identified the determinants of bank performance using panel data of 8 Moroccan banks from 2001 to 2012. The results showed a positive impact by size of banks, foreign direct investment, and financial crisis. Furthermore, a negative impact was found by external funding to total liabilities, share of own bank's capital of the bank's total assets and unemployment rate.

However, other studies used ordinary least squares (OLS) and other econometric estimators. For example, in Europe, Nuhiu et al. (2017) investigated commercial banks profitability determinants in Kosovo. They used OLS on a panel data set of 10 commercial banks spanning 2010 to 2015. The empirical findings concluded that the profitability of commercial Kosovo banks was boosted by the increase in asset quality, management efficiency, GDP and inflation. However, the increment in capital adequacy and liquidity ratios caused a reduction in bank profit. Fidanoski et al. (2018) aimed at determining the effect of bank-specific, industry specific and macro-economic factors on Croatian banks' profitability indicators NIM and ROA. They applied dynamic OLS on a panel of 25 banks from 2007 to 2014. The empirical results proved the important positive impact of bank size, capital strength, loan to total asset, securities, liquidity risk, $\mathrm{HHI}$ (rejecting the structure conduct-performance [SCP] hypothesis, efficiency hypotheses) and GDP on the banks profitability. Further, credit risk, leverage risk, and operating efficiency were negatively related to bank profitability.

In Africa, Abate \& Mesfin (2019) examined the profitability of Ethiopian commercial banks. The study was conducted using a set of 9 banks from 2007 to 2016. To gain the empirical results, a return effect model (REM) was 
utilized and the findings stressed that leverage, capital ratio, liquidity risk, and bank ownership significantly and positively related to banks' profitability. On the other hand, cost to income ratio, GDP, interest rate and inflation were negatively attached to banks' profitability. In Ghana, Doku et al. (2019) studied the profitability of Ghanaian commercial banks. The study incorporated panel corrected standard error (PCSE) on a set of 21 banks from 2000 to 2014. The empirical outcomes indicated that bank profitability was positively related to demand ratio, inflation and equity to total asset, while negatively related to bank size, credit risk, overhead ratio, GDP per capita and total debt to total asset ratio.

In Asia, Prasanto, Wulandari, Narmaditya, \& Kamaludin, (2020) investigated bank profitability determinant of state owned banks during 2007 to 2017 periods. The study used VECM and found that in long term operational risk, loan to deposit ratio, non-performing loans, exchange rate, and economic growth had positive impact on bank profitability. Meanwhile, in the short run none of the mentioned variables had any effect on bank profitability. Arif and Nauman (2012) tested the relationship between liquidity and performance in 22 Pakistani banks from 2004 to 2009. They found that bank profitability was positively related to liquidity and negatively to credit risk. Samad, (2017) examined the profitability of commercial banks in Malaysia. The study used OLS on panel data of 24 commercial banks from 2008 to 2011. The results showed that capital adequacy, efficiency, employee incentives, and diversification were positively correlated to bank profits, whereas credit risk was found to be a significant negative determinant of bank profitability. Furthermore, in regards to external determinants such as market structure, concentration ratio and the macroeconomic variable were found to be insignificant determinants of bank profitability in Malaysia. In Indonesia, Ramadhanti et al. (2019) aimed at determining the impact of capital risk, liquidity risk, and credit risk on bank profitability measured by ROA. The study was conducted on assets of 27 listed banks in the Indonesia Stock Exchange over three years covering 2015 to 2017. The empirical results were stressed that capital risk and liquidity risk were positively and significantly related to ROA. However, credit risk was found to have a significant negative impact on bank ROA. In Jordan, Almumani (2013) tested the impact of managerial factors on commercial bank profitability. He used descriptive analysis, ratio analysis, Pearson correlation, regression, and analysis of variance (ANOVA) methods and applied them on an industrial data set of 13 commercial banks from 2005 to 2011 . The results showed that bank profitability was influenced negatively by the cost to income ratio. Furthermore, liquidity risk, credit composition, credit risk, capital adequacy and bank size were found to be unrelated to bank profitability. Alzorqan, (2014) studied the impact of liquidity risk measured by current ratio and loan to deposit ratio on commercial banks performance in Jordan using fixed effect regression on a panel data of two major banks for 2008 to 2012. The research found a significant negative impact of current ratio and a significant positive impact of loan to deposit ratio on both of the performance indicators ROE and ROI.

Consequently, the current study aimed to assess the determinants of commercial banks profitability in Jordan. Particularly, it empirically evaluated both internal bank factors and external factors that impacted the banks' profitability measured by ROA. This study covered a gap in profitability and financial performance literature in Jordan. Moreover, the current study contributed and extended the prior studies from various countries as it utilized panel data of 13 Jordanian commercial banks spanning periods from 2000 to 2018 and comprehensively employed diverse bank internal and external variables. Through the 5 external variables utilized in this study, the return volatility of each bank, financial development and Syrian refugee crises variables were used for the first time when compared to other past studies of financial performance and banks' profitability in Jordan.

Based on this empirical review, conflicting results were noticed regarding the impact of the internal and external factors on bank profitability. So, this study formulated the following hypotheses to confirm the validity of these results and to achieve its objectives for the Jordanian economy.

$H_{0}$ 1: There was no significant impact of banks' internal factors (credit risk, leverage risk, operational risk, capital risk, bank size and diversification) on commercial banks' profitability in Jordan.

$H_{0}$ 2: There was no significant effect of external factors (market concentration, financial market development, return volatility, inflation, GDP) on commercial banks' profitability in Jordan.

$H_{0} 3$ : There was no significant effect of the Syrian refugees' crisis on commercial banks' profitability in Jordan.

\section{Data Sources and Research Methodology}

In this section, the data sources, variable measurements, expected signs of the relationship between profitability and its determinants, model specification and the methodology are discussed. 


\subsection{Sample and Data Sources}

A sample of all 13 commercial banks operated and still operating in Jordan from 2000 to 2018 are listed in Table 1. A total of 247 observations balanced panel data were obtained. Foreign banks were excluded in this study because of the unavailability of their financial statements. Furthermore, Islamic banks were also excluded as they operate under different principles (Murabaha). For the bank scope, the data was gathered from the Amman Stock Exchange database (http://www.ase.com.jo) by calculating the study variables from bank financial statements directly. Also, the macroeconomic variables data were collected from the World Bank database (http://www.worldbank.org).

Table 1. Commercial banks operating in Jordan

\begin{tabular}{llll}
\hline Ref & \multicolumn{1}{c}{ Bank Name } & Ref & \multicolumn{1}{c}{ Bank Name } \\
\hline 1 & Jordan Kuwait Bank & 8 & Jordan Ahli Bank \\
2 & Jordan Commercial Bank & 9 & Arab Bank \\
3 & The Housing Bank for Trade and Finance & 10 & Cairo Amman Bank \\
4 & Arab Jordan Investment Bank & 11 & Capital Bank \\
5 & Invest Bank & 12 & Arab Banking Corporation (Jordan) \\
6 & Union Bank & 13 & Societe Genrale De Banque - Jordanie \\
7 & Bank of Jordan & & \\
\hline
\end{tabular}

Source: CBJ (2019) database, available online at http://www.cbj.gov.jo.

\subsection{Variables Definitions}

According to the past studies there are two groups of determinants affecting the profitability (return on assets [ROA]). First, there are internal determinants, which are leverage risk $(\mathrm{V})$; operational risk $(\mathrm{O})$; capital risk $(\mathrm{K})$; credit risk (C); bank size (Z); and diversification, (D). Second, there are external variables, which are market concentration (M); financial development $(\mathrm{F})$; return volatility $(\mathrm{T})$; gross domestic product $(\mathrm{G})$; and inflation (I). The definition and expected sign of these variables are summarized in Table 2.

Table 2. Variables, definitions, and expected sign

\begin{tabular}{|c|c|c|c|}
\hline & Variables & Definition & $\begin{array}{l}\text { Expected } \\
\text { sign }\end{array}$ \\
\hline & Return on Asset (ROA) & Profit before interest and tax divided by total assets (\%) & \\
\hline 0 & Capital Risk & Equity to total asset ratio & $-/+$ \\
\hline वै & Credit Risk & Loan loss provision divided by total loans & $-/+$ \\
\hline$\approx$ & Operational Risk & Operating expenses divided by net income & $-/+$ \\
\hline ส & Leverage Risk & Debt to equity ratio & $-/+$ \\
\hline घ & Diversification & Non-interest income divided by total asset & + \\
\hline$\Xi$ & Bank Size & Natural logarithm of total asset & $-/+$ \\
\hline & Market Concentration & HHI index & $-/+$ \\
\hline$\frac{0}{2}$ & Financial Development & Market capitalization divided by bank asset & + \\
\hline ב⿱艹 & Return Volatility & Annualized standard deviation of daily stock return & + \\
\hline$\geq$ & Inflation & $\Delta$ in consumer price index & + \\
\hline Еี & GDP & GDP growth rate & + \\
\hline 齐 & Refugee Crisis & $\begin{array}{l}\text { Dummy variable of } 1 \text { for crises years and } 0 \text { for other } \\
\text { years }\end{array}$ & - \\
\hline
\end{tabular}

Source: Author's construction (2019)

Furthermore, the verifications of these variables by literature review are listed in Table 3. 
Table 3. Verifications of variables

\begin{tabular}{|c|c|}
\hline Variable & Definition and Verification \\
\hline ROA & $\begin{array}{l}\text { Return on assets is a profitability ratio that reflects the capability of a bank's management in generating profits } \\
\text { from the resources used. ROA shows the earned profit from each dollar invested in the business. It is also an } \\
\text { indicator of the efficiency of business management (Ariyadasa et al., 2017). ROA has been used as a } \\
\text { profitability measure in many previous studies (Ariyadasa et al., 2017; Bucevska \& Misheva, 2017; Knezevic } \\
\text { \& Dobromirov, 2016; Paolucci \& Menicucci, 2016; and Chowdhury, 2015). }\end{array}$ \\
\hline $\mathrm{K}$ & $\begin{array}{l}\text { Capital risk is one of the important risk types in any bank. It signifies the strength of the bank's capital. A } \\
\text { sufficient equity amount helps the bank to withstand sudden shocks (Adusei, 2015). In previous literature, it } \\
\text { has been measured by equity to total assets ratio (capital adequacy ratio). }\end{array}$ \\
\hline $\mathrm{C}$ & $\begin{array}{l}\text { Credit risk is measured by the ratio of loan loss provisions to total loans and measures the asset quality. It can } \\
\text { have a negative impact on a bank's profitability since the high ratio of non-performing loans requires a high } \\
\text { reserve ratio that depresses the profitability. However, its effect can also be positive since higher loans } \\
\text { encourages the intermediation margin (Sun et al., 2016). }\end{array}$ \\
\hline $\mathrm{O}$ & $\begin{array}{l}\text { Operational risk is measured by the cost to income ratio (operating expenses divided by net income) and } \\
\text { measures the expenses management quality within a bank. It is expected to have a negative impact on bank } \\
\text { profit (Knezevic \& Dobromirov, 2016). }\end{array}$ \\
\hline $\mathrm{V}$ & $\begin{array}{l}\text { Leverage risk is measured by debt to equity ratio that shows the usage of debt in bank capital. However, if the } \\
\text { value of banks assets is reduced and bad debt is increased, a lower leverage ratio is preferred (Masood \& } \\
\text { Ashraf, 2012). }\end{array}$ \\
\hline $\mathrm{D}$ & $\begin{array}{l}\text { Diversification is calculated by the ratio of non-interest income to total assets. It's expected to have a positive } \\
\text { impact since the non-interest income includes net commission income, gains from financial assets and } \\
\text { instruments, gains from foreign currencies and other revenues (Misra, 2015). }\end{array}$ \\
\hline Z & $\begin{array}{l}\text { Bank size is measured through the log of a bank's total assets. The influence of size depends on a bank's } \\
\text { ability to increase profit through economies of scale. }\end{array}$ \\
\hline M & $\begin{array}{l}\text { Market concentration is related to the structure conduct-performance (SCP) hypothesis or efficiency } \\
\text { hypothesis. HHI is used to examine it. The expected result of this variable can be positive supported by the } \\
\text { SCP or negative supported by the efficiency theory (Athanasoglou et al., 2008; Tan \& Floros, 2012; } \\
\text { Jara-Bertin et al., 2014; Pervan et al., 2015; Knezevic \& Dobromirov, 2016; Saona, 2016; Bucevska \& } \\
\text { Misheva, 2017). }\end{array}$ \\
\hline $\mathrm{F}$ & $\begin{array}{l}\text { Financial development is measured by market capitalization to total assets of commercial banks (Knezevic and } \\
\text { Dobromirov, 2016). However, in their view, it was expected to have a negative or positive impact on bank } \\
\text { profitability. }\end{array}$ \\
\hline $\mathrm{T}$ & $\begin{array}{l}\text { Stock market volatility is related to total risk measured by the annualized standard deviation of daily stock } \\
\text { return (Agusman et al., 2008). According to Tan \& Floros, (2012b), there is a positive relationship between } \\
\text { bank profitability and return volatility, meaning that more risky banks achieve more profit. }\end{array}$ \\
\hline I & $\begin{array}{l}\text { Inflation is measured by the change in the consumer price index. By economic theory inflation rate has a major } \\
\text { role in the interest rate structure. Thus, a higher inflation rate leads to a higher interest rate on loans, which } \\
\text { increases the bank profitability (Pervan et al., 2015). }\end{array}$ \\
\hline $\mathrm{G}$ & $\begin{array}{l}\text { GDP was included in many previous studies as one determinant of bank profitability and its effect can be } \\
\text { positive (Sufian, 2012; Mokni \& Rachdi, 2014; Jara-Bertin et al., 2014, Pervan et al., 2015; Ozili, 2016; and } \\
\text { Zarrouk et al., 2016). Also, it can be negative (Tan \& Floros, 2012a). }\end{array}$ \\
\hline $\mathrm{R}$ & $\begin{array}{l}\text { Refugee crisis is measured by a dummy value of } 1 \text { for the refugee crisis years ( } 2011 \text { to } 2018) \text { and zero for } \\
\text { other years. This variable is expected to have a negative impact on profitability ratios. It takes into account the } \\
\text { geopolitical effects of the Arab Spring that also affected the Jordanian economy negatively. }\end{array}$ \\
\hline
\end{tabular}

Source: Compiled by past studies.

\subsection{Methodology Specification and Model Construction}

To investigate factors affecting bank profitability, many steps for methodology were used. The initial step was to check the behavior and quality of the data. So, the descriptive statistics are essential at this stage. Bekhet \& Al-Smadi, (2015) stressed that in the case of non-stationary time series, regression analysis would not be true. However, in the 
current study, augmented Dickey- Fuller (ADF), Im, Persan and Shin (IPS), Phillips-Perron (PP), and Levin, Lin and Chu (LLC) tests were conducted to check the data stationarity.

Almaqtari et al., (2019) have stated that functional linear regression is appropriate when analyzing bank profitability determinants. So, many previous studies have utilized OLS, fixed effect, and/or random effect models (see Nuhiu et al., 2017; Abate \& Mesfin, 2019; Petria et al., 2015; Paolucci, 2016). Some other studies used both linear regression and generalized method of moments, GMM (see, Saona, 2016; Bucevska and Misheva, 2017). However, Roodman (2009) confirmed that GMM is suitable in situations, such as large N and small T, Regressors are not strictly exogenous, the existence of fixed individual effect, heteroscedasticity, and autocorrelation. Moreover, according to Saona (2016) the presence of problems related to individual heterogeneity that does not exist in this study is a good justification for using GMM. However, both difference and system of GMM can be inconsistent in case of instrument near unit root properties (Almaqtari et al., 2019). Furthermore, Gujarati \& Porter (2008) confirmed that adopting panel data analysis has many advantages. The first is its ability to take care of possible heterogeneity. Second, the combination of time series and cross sectional data gives more efficient estimation. Based on the above, this study applied static regression techniques with OLS, FEM, and REM.

Annual balanced panel data for the study variables from 2000 to 2018 was utilized. Data with the dimensions of time series for 2000 to 2018 (i.e. $\mathrm{t}=1, \ldots \ldots, \mathrm{T}$ ) and cross sections (i.e. $\mathrm{i}=1, \ldots \ldots, \mathrm{N}$ ) is known as the panel data set and the observation number is ( $\mathrm{i} \times \mathrm{t}=247$ ). However, according to Brooks, (2008) the general framework of a panel data regression is defined as in Equation 1.

$$
y_{i t}=\alpha_{i}+\beta_{j} X_{i t}+\varepsilon_{i t} \quad(i=1,2, \ldots N ; t=1,2, \ldots T)
$$

Where $\mathrm{y}_{t}$ is the dependent variable (profitability); $\alpha_{\mathrm{i}}$ is the intercept; $\beta_{\mathrm{j}}$ is the coefficients to be estimated; $\mathrm{X}_{i}$ is the set of explanatory variables (internal and external factors); $\varepsilon_{\mathrm{it}}$ represent the error term. For measuring impact of the internal and external factors on Jordanian commercial banks profitability, Equation 1 is extended by including the internal and external variables (see Table 3) as shown in Equation 2.

$$
R O A_{i t}=\alpha_{i}+\left(\beta_{1} \mathrm{~K}_{i t}+\beta_{2} \mathrm{C}_{i t}+\beta_{3} \mathrm{O}_{i t}+\beta_{4} \mathrm{~V}_{i t}+\beta_{5} \mathrm{D}_{i t}+\beta_{6} \mathrm{Z}_{i t}\right)+\left(\beta_{7} \mathrm{M}_{i t}+\beta_{8} \mathrm{~F}_{i t}+\beta_{9} \mathrm{~T}_{i t}+\beta_{10} \mathrm{I}_{i t}+\beta_{11} \mathrm{G}_{i t}\right)+\beta_{12} \mathrm{R}_{i t}+\varepsilon_{i t}
$$

The model is estimated through OLS, fixed effect model (FEM), and random effect model (REM). Furthermore, LM test and Huasman tests are used to determine the most efficient model among them. For robustness of the results, feasible generalized least square (FGLS) is applied.

\section{Analysis and Discussion of Results}

\subsection{Descriptive Results}

Descriptive statistics of the variables of this study is shown in Table 4. It reveals the mean, minimum, maximum, standard deviation, and number of observations. Precisely, the minimum value of ROA is -0.05 whereas the maximum value is 0.05 percent. The mean value is 0.01 percent and standard deviation is 0.01 percent. Also, Table 4 shows that for internal variables, the average value of the bank size is 9.13 , the ratios of credit risk, diversification, capital, operational risk, and leverage risk are $7 \%, 2 \%, 13 \%, 3 \%$, and $7 \%$ with standard deviations of $8 \%, 1 \%, 4 \%$, $5 \%$, and $4 \%$ respectively. With consideration of external variables, the mean values of market concentration, financial development, return volatility, inflation, and GDP are 34\%, 18\%, 24\%, 3\%, and 5\% with standard deviations of $8 \%, 12 \%, 140 \%, 3 \%$, and $2 \%$ respectively.

Table 4. Descriptive statistics

\begin{tabular}{ccccccccccccc}
\hline Index & ROA & $\mathrm{C}$ & $\mathrm{D}$ & $\mathrm{K}$ & $\mathrm{O}$ & $\mathrm{V}$ & $\mathrm{Z}$ & $\mathrm{M}$ & $\mathrm{F}$ & $\mathrm{T}$ & $\mathrm{I}$ & $\mathrm{G}$ \\
\hline Mean & 0.01 & 0.07 & 0.02 & 0.13 & 0.03 & 0.07 & 9.13 & 0.34 & 0.18 & 0.24 & 0.03 & 0.05 \\
Maximum & 0.05 & 0.90 & 0.14 & 0.31 & 0.62 & 0.26 & 10.41 & 0.47 & 0.66 & 18.84 & 0.15 & 0.09 \\
Minimum & -0.05 & 0.003 & -0.02 & 0.03 & -0.11 & 0.00 & 7.73 & 0.23 & 0.03 & 0.01 & -0.01 & 0.02 \\
Std. Dev. & 0.01 & 0.08 & 0.01 & 0.04 & 0.05 & 0.04 & 0.52 & 0.08 & 0.12 & 1.40 & 0.03 & 0.02 \\
Observations & 247 & 247 & 247 & 247 & 247 & 247 & 247 & 247 & 247 & 247 & 247 & 247 \\
\hline
\end{tabular}

Source: Output of the EViews 9 econometric software.

\subsection{Correlation Matrix Analysis}

Table. 5 shows the interrelationship among the variables. It shows a negative interrelationship between credit risk and ROA (-0.34) at $1 \%$ significant level, which is consistent with the studies of Ozili (2017) and Batten \& Vo (2019). 
Nevertheless, suggesting the same results of Adusei (2015), there is a positive and significant interrelationship between bank profitability on one hand and diversification and capital on the other hand $(r=0.24, r=0.19)$ respectively. In addition, operational risk, leverage risk, and market concentration have a negative and significant association with ROA ( $r=-0.22, r=-0.14$, and $r=-0.11)$ respectively. These results supported the results of Petria et al. (2015) for operational risk and diversification and contradicted the study of Alshatti (2016) for the financial leverage. Furthermore, other researchers (Knezevic \& Dobromirov, 2016; Bogdan \& Ihnatov, 2014) confirmed that financial development, inflation and GDP expressed a significant and positive correlation to bank profit $(r=0.49, r=$ 0.19 , and $r=0.25$ ) respectively. Finally, the refugee crisis showed a low-level negative association with bank profit $(r=-0.07)$ and was insignificant.

Table 5. Correlation matrix analysis

\begin{tabular}{|c|c|c|c|c|c|c|c|c|c|c|c|c|c|}
\hline Variables & ROA & C & D & $\mathbf{K}$ & $\mathbf{O}$ & $\bar{V}$ & $\mathbf{Z}$ & $\mathbf{M}$ & $\mathbf{F}$ & $\mathbf{T}$ & I & G & $\mathbf{R}$ \\
\hline ROA & 1.00 & & & & & & & & & & & & \\
\hline $\mathbf{C}$ & $-0.34^{a}$ & 1.00 & & & & & & & & & & & \\
\hline D & $0.24^{\mathrm{a}}$ & $0.24^{\mathrm{a}}$ & 1.00 & & & & & & & & & & \\
\hline $\mathbf{K}$ & $0.19^{\mathrm{a}}$ & $0.15^{\mathrm{b}}$ & 0.03 & 1.00 & & & & & & & & & \\
\hline $\mathbf{O}$ & $-0.22^{\mathrm{a}}$ & $0.16^{\mathrm{b}}$ & 0.05 & -0.04 & 1.00 & & & & & & & & \\
\hline $\mathbf{v}$ & $-0.14^{\mathrm{b}}$ & 0.05 & -0.08 & $-0.71^{\mathrm{a}}$ & 0.02 & 1.00 & & & & & & & \\
\hline $\mathbf{Z}$ & 0.07 & $-0.35^{\mathrm{a}}$ & $-0.24^{\mathrm{a}}$ & 0.03 & -0.004 & 0.01 & 1.00 & & & & & & \\
\hline $\mathbf{M}$ & $-0.11^{c}$ & $-0.35^{\mathrm{a}}$ & $0.20^{\mathrm{a}}$ & $-0.39^{a}$ & -0.03 & $0.43^{\mathrm{a}}$ & $-0.46^{\mathrm{a}}$ & 1.00 & & & & & \\
\hline $\mathbf{F}$ & $0.49^{\mathrm{a}}$ & $0.34^{\mathrm{a}}$ & $0.24^{\mathrm{a}}$ & $0.33^{\mathrm{a}}$ & $-0.18^{a}$ & $-0.27^{\mathrm{a}}$ & 0.03 & 0.07 & 1.00 & & & & \\
\hline $\mathbf{T}$ & -0.01 & -0.03 & -0.02 & -0.06 & -0.03 & 0.05 & $0.26^{\mathrm{a}}$ & 0.09 & $0.28^{\mathrm{a}}$ & 1.00 & & & \\
\hline I & $0.19^{\mathrm{a}}$ & -0.04 & 0.00 & $0.18^{\mathrm{a}}$ & $-0.14^{b}$ & $-0.15^{\mathrm{b}}$ & 0.03 & -0.05 & $0.21^{\mathrm{a}}$ & 0.00 & 1.00 & & \\
\hline G & $0.25^{\mathrm{a}}$ & $-0.11^{c}$ & $0.26^{\mathrm{a}}$ & -0.07 & $-0.14^{b}$ & 0.09 & $-0.27^{\mathrm{a}}$ & $0.56^{\mathrm{a}}$ & $0.56^{\mathrm{a}}$ & $0.17^{\mathrm{a}}$ & $0.31^{\mathrm{a}}$ & 1.00 & \\
\hline $\mathbf{R}$ & -0.07 & 0.10 & $-0.17^{\mathrm{a}}$ & $0.20^{\mathrm{a}}$ & 0.09 & $-0.25^{\mathrm{a}}$ & $0.37^{\mathrm{a}}$ & $-0.79^{\mathrm{a}}$ & $-0.32^{\mathrm{a}}$ & $-0.11^{c}$ & $-0.15^{\mathrm{c}}$ & $-0.73^{\mathrm{a}}$ & 1.00 \\
\hline
\end{tabular}

Notes: a, b, c indicates significant at $1 \%, 5 \%$ and $10 \%$ levels respectively.

\subsection{Unit Root and Cointegration Analysis}

Table 6 shows the results and decision of the augmented Dickey-Fuller (ADF), Im, Persan and Shin (IPS), Phillips-Perron (PP), and Levin, Lin and Chu (LLC) tests at both constant and trend with different significance levels. It shows the ROA, credit risk, leverage risk, operation risk, diversification, return volatility, financial development, inflation, and GDP are stationary at level, i.e., $I(0)$. However, the remaining variables of capital risk, size, market concentration, are stationary at first difference, i.e., $I(1)$.

Table 6. Stationary tests results

\begin{tabular}{|c|c|c|c|c|c|c|c|c|c|c|}
\hline \multirow{2}{*}{\multicolumn{2}{|c|}{ Variables }} & \multicolumn{2}{|c|}{ ADF } & \multicolumn{2}{|c|}{ IPS } & \multicolumn{2}{|c|}{$\mathbf{P P}$} & \multicolumn{2}{|c|}{ LLC } & \multirow{2}{*}{ Decision } \\
\hline & & $I(0)$ & $I(1)$ & $I(0)$ & $I(1)$ & $I(0)$ & $I(1)$ & $I(0)$ & $I(1)$ & \\
\hline \multicolumn{2}{|l|}{ ROA } & $77.62^{\mathrm{a}}$ & $177.65^{\mathrm{a}}$ & $-5.53^{\mathrm{a}}$ & $-13.14^{\mathrm{a}}$ & $90.21^{\mathrm{a}}$ & $280.54^{\mathrm{a}}$ & $-5.42^{\mathrm{a}}$ & $-15.33^{\mathrm{a}}$ & $\mathrm{I}(0)$ \\
\hline \multirow{6}{*}{$\begin{array}{l}\text { Internal } \\
\text { determinants }\end{array}$} & $\mathrm{C}$ & $55.51^{\mathrm{a}}$ & $84.71^{\mathrm{a}}$ & $-3.49^{\mathrm{a}}$ & $-6.21^{a}$ & $19.44^{\mathrm{a}}$ & $60.41^{\mathrm{a}}$ & $-2.39^{a}$ & $-7.16 a$ & $\mathrm{I}(0)$ \\
\hline & D & $81.44^{\mathrm{a}}$ & $118.41^{\mathrm{a}}$ & $-5.61^{\mathrm{a}}$ & $-9.25^{\mathrm{a}}$ & $82.24^{\mathrm{a}}$ & $176.01^{\mathrm{a}}$ & $-4.89^{a}$ & $-10.52^{\mathrm{a}}$ & $\mathrm{I}(0)$ \\
\hline & K & 19.18 & $116.24^{\mathrm{a}}$ & 0.93 & $-12.17^{\mathrm{a}}$ & 23.62 & $140.82^{c}$ & $-1.52^{\mathrm{a}}$ & $-20.38^{a}$ & $\mathrm{I}(1)$ \\
\hline & $\mathrm{O}$ & $91.89^{\mathrm{a}}$ & $139.56^{\mathrm{a}}$ & $-6.93^{\mathrm{a}}$ & $-11.22^{\mathrm{a}}$ & $97.58^{\mathrm{a}}$ & $200.44^{\mathrm{a}}$ & $-7.86^{\mathrm{a}}$ & $-3.15^{\mathrm{a}}$ & $\mathrm{I}(0)$ \\
\hline & V & $54.71^{\mathrm{a}}$ & $127.36^{\mathrm{a}}$ & $-2.76^{\mathrm{a}}$ & $-11.74^{\mathrm{a}}$ & $42.73^{\mathrm{a}}$ & $187.44^{\mathrm{a}}$ & $-8.23^{\mathrm{a}}$ & $-14.82^{\mathrm{a}}$ & $\mathrm{I}(0)$ \\
\hline & $\mathrm{Z}$ & 27.06 & $95.85^{\mathrm{a}}$ & 0.52 & $-7.60 \mathrm{a}$ & 15.16 & $88.18^{\mathrm{a}}$ & 0.00 & $-9.44^{a}$ & $\mathrm{I}(1)$ \\
\hline \multirow{5}{*}{$\begin{array}{l}\text { External } \\
\text { determinants }\end{array}$} & $\bar{M}$ & 6.25 & $114.93^{\mathrm{a}}$ & 2.62 & $-9.28^{\mathrm{a}}$ & 9.35 & $62.18^{\mathrm{a}}$ & 1.70 & $-14.36^{\mathrm{a}}$ & $\mathrm{I}(1)$ \\
\hline & $\mathrm{F}$ & $90.15^{\mathrm{a}}$ & $92.96^{\mathrm{a}}$ & $-7.01^{\mathrm{a}}$ & $-7.21^{\mathrm{a}}$ & 32.60 & $106.49^{a}$ & $-8.14^{\mathrm{a}}$ & $-8.56^{\mathrm{a}}$ & $\mathrm{I}(0)$ \\
\hline & $\mathrm{T}$ & $38.51^{\mathrm{c}}$ & $95.99^{\mathrm{a}}$ & $-2.03^{\mathrm{b}}$ & $-7.55^{\mathrm{a}}$ & 25.07 & $130.84^{\mathrm{a}}$ & $-4.18^{a}$ & $-11.11^{\mathrm{a}}$ & $\mathrm{I}(0)$ \\
\hline & I & $92.44^{\mathrm{a}}$ & $242.99^{\mathrm{a}}$ & $-7.37^{\mathrm{a}}$ & $-20.79^{a}$ & $92.34^{\mathrm{a}}$ & $308.94^{\mathrm{a}}$ & $-6.46^{\mathrm{a}}$ & $-20.40^{\mathrm{a}}$ & $\mathrm{I}(0)$ \\
\hline & G & $134.74^{\mathrm{a}}$ & $137.50^{\mathrm{a}}$ & $-10.15^{\mathrm{a}}$ & $-11.24^{\mathrm{a}}$ & 30.37 & $137.80^{\mathrm{a}}$ & $-12.71^{a}$ & $-15.82^{\mathrm{a}}$ & $\mathrm{I}(0)$ \\
\hline
\end{tabular}

Notes: $\mathrm{a}, \mathrm{b}$, and c denote statistically significance at $1 \%, 5 \%$, and $10 \%$ levels respectively.

Source: Output of the E-views 9 econometric software. 
Based on the above results, the best way to analyze mixed level integrated data is a panel cointegration approach (Ariyadasa et al., 2017). In addition, Barbieri (2008) ensured that panel cointegration tests lose their power in the case of small time dimension and starts gaining power if T is 25 and more. Thus, the KAO (1999) test is employed to check the cointegration among the variables and the results are shown in Table 7. So, it confirms that there is a cointegration among the variables. However, it revealed a rejection of the null hypothesis (i.e. $\mathrm{H}_{0}=$ no cointegration) and accepted alternative hypothesis $\left(\mathrm{H}_{1}=\right.$ there is cointegration among the variables $)$.

Table 7. Kao Test for cointegration

\begin{tabular}{|c|c|c|}
\hline \multicolumn{3}{|c|}{ Ho: No cointegration, $\mathrm{H}_{1}$ : All panels are cointegrated } \\
\hline & t-Statistic & Prob. \\
\hline $\mathrm{ADF}$ & -5.39389 & 0.00 \\
\hline Residual variance & 0.00006 & \\
\hline HAC variance & 0.00003 & \\
\hline
\end{tabular}

Source: Output of the EViews 9 econometric software.

\subsection{Panel Data Model Estimation}

To gain the objectives of this study through testing its hypotheses, pooled OLS, FEM and REM methods are applied in Equations 2 as shown in subsection 4.3. Theoretically, OLS assumes a similarity in the intercept across years and banks. Fixed and random effect models assume that the variance is constant. The results of the above models are shown in Table 8.

Both the Wooldridge test for serial correlation and the modified Wald test for groupwise heteroscedasticity hypothesis were rejected, confirming the existence of these problems. For the reliability of the model used, $\mathrm{R}^{2}$ shows that independent variables interpret $51 \%$ of the variance of the ROA variable, which is satisfactory according to previous literature (Almaqtari et al., 2019). Also, the results of the F-test show that the model fits the data well with a value of 20.07 (0.0000). Also, the Hausman test was conducted for deciding the best model between fixed effect and random effect models. The finding confirms the appropriateness and the superiority of the FEM over the REM since the P-value is less than 5\% (0.0000).

Table 8. Results of models

\begin{tabular}{clcc}
\hline Variables & OLS & Random & Fixed \\
\hline C & $-0.0254 * * *$ & $-0.0210 * * *$ & $-0.0139 * *$ \\
$\mathrm{D}$ & $0.1324 * * *$ & $0.1234 * * *$ & $0.1208 * * *$ \\
$\mathrm{~K}$ & 0.0071 & 0.0126 & 0.0209 \\
$\mathrm{O}$ & $-0.0245 * * *$ & $-0.0254 * * *$ & $-0.0249 * * *$ \\
$\mathrm{~V}$ & -0.0017 & -0.0135 & $-0.0488 * * *$ \\
$\mathrm{Z}$ & 0.0173 & $0.0207 *$ & $0.0269 * *$ \\
$\mathrm{M}$ & $-0.0932 * *$ & $-0.0849 * * *$ & $-0.0660 *$ \\
$\mathrm{~T}$ & -0.0008 & $-0.0007 * *$ & $-0.0006 * *$ \\
$\mathrm{~F}$ & $0.0277 * * *$ & $0.0287 * * *$ & $0.0298 * * *$ \\
$\mathrm{I}$ & $0.0296 *$ & $0.0273 *$ & 0.0216 \\
$\mathrm{G}$ & -0.0363 & -0.0395 & -0.0435 \\
$\mathrm{R}$ & -0.0002 & $-0.00005 *$ & -0.0004 \\
Constant & $0.0062 * * *$ & $0.0072 * * *$ & $0.0095 * * *$ \\
$\mathrm{R}$ & 0.4438 & 0.4989 & 0.5129 \\
No. of Obs. & 234 & 234 & 234 \\
F value & $14.70 * * *$ & & $15.62 * * *$ \\
\hline
\end{tabular}

Notes: (1) $* * *, * *, *$ indicates significant at 1,5 and $10 \%$ levels respectively.

(2) Wald Chi test $=192.16^{* * *}$, Hausman Test $=33.81^{* * *}$, LM Statistics $=55.73^{* * *}$ 
First, Table 8 reveals that most of the internal and external variables show a significant impact on bank profitability and to some extent the impact is the same among the three estimation techniques. Internal factors follow most of the previous literature and credit risk showed a significant negative association with ROA. These results were emphasized in many previous studies (Jara-Bertin et al., 2014; Chowdhury, 2015; Paolucci \& Menicucci, 2016; Bucevska \& Misheva, 2017). Moreover, the results contradict some other studies (Sufian, 2012; Tan \& Floros, 2012; Sun et al., 2016) that found a positive impact of credit risk on bank profitability. Also, diversification is significant in Jordanian commercial bank profitability and it shows a positive impact on bank profitability. This association is important to bank management because it represents that more diversification means more profit. This significant positive impact of diversification was also found in ( Arif and Nauman, 2012; Saona, 2016; Jara-Bertin et al., 2014; and Bucevska and Misheva, 2017) On the other hand, though it was insignificant capital risk recorded a positive impact on bank profitability, stressing that a bank with a higher equity to capital ratio earns more than banks that are lower. These results are in line with many studies (Masood \& Ashraf, 2012; Bogdan \& Ihnatov, 2014; Misra 2015; Alshatti 2016; and Sun et al., 2016).

In line with expectations, operational risk had a negative effect on commercial bank profitability in Jordan, which emphasizes that bank management should manage its operating costs efficiently to gain more profit. This result supports previous studies (Garcia \& Guerreiro, 2016; Zarrouk et al., 2016; Ariyadasa et al., 2017) and contradicts the results of Bougatef (2017). One more result was that financial leverage was significant and had a negative impact on commercial bank profitability in Jordan, implying that financing with more debt generates less profit. However, these results contradict the results of other researchers (Masood \& Ashraf, 2012, Alshatti, 2016).The positive and significant results of bank size on profitability were found in both FEM and REM but not in OLS and showed that banks in Jordan are benefiting from their economies of scale. These positive outcomes support the results of prior studies (Jara-Bertin et al., 2014; Pervan et al., 2015; Ahmad et al., 2016; Saona, 2016; Paolucci \& Menicucci, 2016). However, these findings contradict the results of (Ozili, 2017) study.

Second, for external factors, supported by the efficient market hypothesis, market concentration showed a significant negative impact on bank profitability in Jordan. Such results suggest that banks operating efficiently possess the market power. This finding supports other studies (Petria et al., 2015; Batten and Vo, 2019) and is contrary to some findings (Tan \& Floros, 2012a; Marijana et al., 2012; Pervan et al., 2015; Knezevic \& Dobromirov, 2016). The positive and significant impact of inflation on commercial banks profitability reflects the full anticipation ability the sector had over the study period, which made it easier for banks to adjust their interest rates to gain more profit. These results are in line with some studies (Jara-Bertin et al., 2014; Al-Homaidi et al., 2018; Batten and Vo, 2019) and are in contrast with others (Pervan et al., 2015). Contrasting the results of Knezevic \& Dobromirov, (2016) financial development expressed a significant positive impact on bank profitability in Jordan. This means that the Jordanian financial market is well developed, which leads to an increase in the potential customer's number and the availability of information that in turn enhances borrowers monitoring and increases the banks' activities and profitability. Through OLS, REM, and FEM return volatility showed a negative impact on ROA. However, this impact was significant when estimating FEM and REM only. This result means the more volatile the stock market returns the less is the banks profit.

Third, the results stated that refugee crisis had a negative impact on bank profitability when using the three estimation techniques, nevertheless, the impact was significant when using REM only. However, this result indicates that bank profitability might increase once the crisis comes to an end. Finally, GDP did not impact significantly on the ROA in any of the models used.

\subsection{Robustness Analysis}

To check the credibility of the results above feasible generalized least square (FGLS) is applied. Öhman \& Yazdanfar, (2018) confirmed that FGLS can overcome problems such as heteroscedasticity, serial correlation, and panel error structure. This means that FGLS is robust against heteroscedasticity and serial correlation. It is more appropriate when $\mathrm{T}$ is $>\mathrm{N}$ (Almaqtari et al., 2019). Table 9 provides the results of this method. 
Table 9. Results of FGLS

\begin{tabular}{ccccc}
\hline Variables & FGLS & Std. Err. & $\mathbf{Z}$ & $\mathbf{P}>|\mathbf{z}|$ \\
\hline C & $-0.0254^{* * *}$ & 0.0058 & -4.38 & 0.000 \\
D & $0.1324^{* * *}$ & 0.0393 & 3.37 & 0.001 \\
K & -0.0072 & 0.0234 & -0.31 & 0.759 \\
O & $-0.0245^{* * *}$ & 0.0081 & -3.02 & 0.003 \\
V & -0.0017 & 0.0146 & 0.12 & 0.906 \\
Z & 0.0173 & 0.0111 & 1.56 & 0.120 \\
M & $-0.0932^{* *}$ & 0.0394 & -2.37 & 0.018 \\
T & $-0.0008^{* * *}$ & 0.0003 & -2.59 & 0.010 \\
F & $0.0277^{* * *}$ & 0.0054 & 5.05 & 0.000 \\
I & $0.0296^{* *}$ & 0.0149 & 1.99 & 0.047 \\
G & -0.0363 & 0.0333 & -1.09 & 0.276 \\
R & -0.0002 & 0.0013 & 0.20 & 0.839 \\
Constant & $0.0062^{* * *}$ & 0.0023 & 2.67 & 0.008 \\
\hline
\end{tabular}

Notes: (1) ***,**, * indicates significant at 1, 5 and $10 \%$ levels respectively.

(2) Wald Chi Test $=192.16^{* * *}$

With reference to internal variables and profitability, FGLS indicates that credit risk and operational risk have a significant negative impact on bank profitability. Both of these variables were found significant at $1 \%(\mathrm{P}$ value $<.01)$ level. On another hand, diversification has a positive impact and it also is significant at $1 \%$ ( $\mathrm{P}$ value $<.01$ ) significance level. However, most of external variables expressed a significant impact on bank profitability. Market concentration, stock market volatility, and financial development are significant at the level of $1 \%(\mathrm{P}<.01)$ but inflation is significant at the level of $5 \%(\mathrm{P}<.05)$. The impact of market concentration and stock market volatility is negative while financial development and inflation expresses a positive impact on profitability.

\section{Conclusions and Policy Implications}

The main goal of this study was to examine the impact of bank specific, industry specific, macroeconomic, and refugee crisis factors on the profitability of commercial banks listed on the Amman Stock Exchange. The study used a balanced panel data set of 13 commercial banks from 2000 to 2018. The estimation results stressed that commercial bank profitability in Jordan is affected positively by diversification and bank size, while negatively affected by credit risk, operational risk, capital risk and leverage risk as internal factors. As for external factors, the results suggested that profitability was positively impacted by financial development and inflation while negatively associated to market concentration, stock market volatility, GDP and refugee crisis. These results were supported by many researchers as noted in section 5.4.

This study covers a knowledge gap by providing new empirical analyses on internal and external factors affecting commercial bank profitability in Jordan. The study is a major contribution to the existing literature by comprehensively analyzing and shading the current state of Jordanian commercial bank profitability. The study gives attention to the crucial events the sector witnessed during the study period such as the Syrian refugee crisis. In addition, a unique contribution of this study is examining the impact of stock market volatility, financial development and the Syrian refugee crisis on Jordanian commercial bank profitability. Furthermore, the results of this study suggest many policy implications. First, managers of banks in Jordan should concentrate more on equity instead of debt in their capital. Second, more attention should be given to diversification and credit risk. Third, banks should concentrate more on optimizing their operational expenses. Finally, this study omitted some external variables such as taxation, interest rate and exchange rate. Therefore, it suggests that further studies take these variables into consideration.

\section{References}

Abate, T. W., \& Mesfin, E. A. (2019). Factors Affecting Profitability of Insurance Companies in Ethiopia. International Journal of Research and Analytical Reviews, 6(1), 881-891.

Adusei, M. (2015). Bank profitability: Insights from the rural banking industry in Ghana. Cogent Economics \& Finance, 3(1), 1-15. https://doi.org/10.1080/23322039.2015.1078270

Ahmad, R., Koh, E., \& Shaharuddin, S. (2016). Determinants of bank profitability: a comparative study of East Asia and Latin America. Int. J. Banking, Accounting and Finance, 7(1), 34-51.

Al-Homaidi, E. A., Tabash, M. I., Farhan, N. H. S., Almaqtari, F. A., \& McMillan, D. (2018). Bank-Specific and 
Macro-Economic determinants of profitability of Indian commercial banks: A panel data approach. Cogent Economics \& Finance, 6(1), 1-35. https://doi.org/10.1080/23322039.2018.1548072

Ali, M., \& Puah, C. H. (2018). The internal determinants of bank profitability and stability. Management Research Review, 42(1), 49-67. https://doi.org/10.1108/MRR-04-2017-0103

Almaqtari, F. A., Al-Homaidi, E. A., Tabash, M. I., \& Farhan, N. H. (2019). The determinants of profitability of Indian commercial banks : A panel data approach. International Journal of Finance \& Economics, 24(1), 168185. https://doi.org/10.1002/ijfe.1655

Almumani, M. A. (2013). Impact of Managerial Factors on Commercial Bank Profitability: Empirical Evidence from Jordan. International Journal of Academic Research in Accounting, Finance and Management Sciences, 3(3), 298-310. https://doi.org/10.6007/IJARAFMS/v3-i3/203

Alshatti, A. S. (2016). Determinants of banks' profitability - The case of Jordan. Investment Management and Financial Innovations, 13(1), 84-91.

Alzorqan, S. T. (2014). Bank liquidity risk and performance : an empirical study of the banking system in Jordan. Research Journal of Finance and Accounting, 5(12), 155-165.

Amin, M. A. M., Sanusi, N. A., Kusairi, S., \& Abdallah, Z. M. (2014). Inverse relationship of financial risk and performance in commercial banks in Tanzania. Investment Management and Financial Innovations, 11(4), 279291.

Arafat, Y., Warokka, A., Buchdadi, A., \& Suherman. (2013). Banking efficiency and performance: a test of banking characteristics in an emerging market. J. for Global Business Advancement, 6(1), 13-23. https://doi.org/10.1504/JGBA.2013.053475

Arif, A., \& Nauman, A. (2012). Liquidity Risk and Performance of Banking System. Journal of Financial Regulation and Compliance, 20(2), 182-195. https://doi.org/10.1108/13581981211218342

Ariyadasa, C., Selvanathan, E. A., Siddique, M. A. B., \& Selvanathan, S. (2017). On the profitability of commercial banks: the Sri Lankan case. Applied Economics, 49(21), 2106-2116. https://doi.org/10.1080/00036846.2016.1231909

Athanasoglou, P., Brissimis, S., \& Delis, M. (2008). Bank-specific, industry-specific and macroeconomic determinants of bank profitability. International Financial Markets, Institutions \& Money, 18(1), 121-136. https://doi.org/10.1016/j.intfin.2006.07.001

Awraq investment. (2015). Jordan Banking Sector Brief 2015.

Barbieri, L. (2008). Panel Cointegration Tests : A Survey. Rivista Internazionale Di Scienze Sociali, 116(1), 3-36. https://doi.org/10.2307/41625199

Batten, J., \& Vo, X. V. (2019). Determinants of Bank Profitability - Evidence from Vietnam. Emerging Markets Finance and Trade, 55(6), 1417-1428. https://doi.org/10.1080/1540496X.2018.1524326

Bekhet, H. A., \& Al-Smadi, R. W. (2015). Determinants of Jordanian foreign direct investment inflows: Bounds testing approach. Economic Modelling, 46(2), 27-35. https://doi.org/10.1016/j.econmod.2014.12.027

Bekhet, H. A., \& Al-Smadi, R. W. (2017). Exploring the long-run and short-run elasticities between FDI inflow and its determinants in Jordan. International Journal of Business and Globalisation, 18(3), 337-362. https://doi.org/10.1504/IJBG.2017.10003128

Bekhet, H. A., \& Eletter, S. F. K. (2012). Credit Risk Management for the Jordanian Commercial Banks : A business Intelligence. Australian Journal of Basic and Applied Sciences, 6(9), 188-195.

Bekhet, H. A., \& Matar, A. (2013). Co-integration and causality analysis between stock market prices and their determinates in their determinates in Jordan. Economic Modelling, 35(11), 508-514. https://doi.org/10.1016/j.econmod.2013.07.012

Bogdan, C., \& Ihnatov, I. (2014). Banks ' Profitability in Selected Central a nd Eastern European Countries. Procedia Economics and Finance, 16(5), 587-591. https://doi.org/10.1016/S2212-5671(14)00844-2

Bongini, P., Cucinelli, D., Battista, M. L. Di, \& Nieri, L. (2018, September). Profitability shocks and recovery in time of crisis evidence from European banks. Finance Research Letters, 1-7. https://doi.org/10.1016/j.frl.2018.10.003

Bougatef, K. (2017). Determinants of bank profitability in Tunisia: does corruption matter?. Journal of Money Laundering Control, 20(1), 70-78. https://doi.org/10.1108/JMLC-10-2015-0044

Brooks, C. (2008). Introductory Econometrics for Finance (2nd ed.). Cambridge. 
Bucevska, V., \& Misheva, B. (2017). The Determinants of Profitability in the Banking Industry: Empirical Research on Selected Balkan Countries. Eastern European Economics, 55(2), 1-22. https://doi.org/10.1080/00128775.2016.1260473

CBJ, C. bank of J. (2016). Central Bank Annual Report 2016.

CBJ, C. bank of J. (2018). Financial Stability Report 2018.

Chowdhury, R. H. (2015). Equity Capital and Bank Profitability: Evidence from the United Arab Emirates. Afro-Asian Journal of Finance and Accounting, 5(1), 1-20. https://doi.org/10.1504/AAJFA.2015.067802

Doku, J. N., Kpekpena, F. A., \& Boateng, P. Y. (2019). Capital Structure and Bank Performance: Empirical Evidence from Ghana. African Development Review, 31(1), 15-27. https://doi.org/10.1111/1467-8268.12360

Dq, T., \& Ngo, T. (2020). The determinants of bank pro fi tability: A cross-country analysis. Central Bank Review Journal, 20, 65-73. https://doi.org/10.1016/j.cbrev.2020.04.001

Ercegovac, R., Klinac, I., \& Zdrilić, I. (2020). Bank Specific Determinants of EU Banks Profitability After 2007 Financial Crisis. Journal of Contemporary Management Issues, 25(1), 89-102. https://doi.org/https://doi.org/10.30924/mjcmi.25.1.5

Ferrouhi, E. M. (2014). Bank Liquidity and Financial Performance: Evidence from Moroccan Banking Industry. Business: Theory and Practice, 15(4), 351-361. https://doi.org/10.3846/btp.2014.443

Fidanoski, F., Choudhry, M., Davidovic, M., \& Sergi, B. (2018). What does affect profitability of banks in Croatia? Competitiveness Review: An International Business Journal, 28(4), 338-367.

Francis, A. (2015). Jordan'S Refugee Crisis. Retrieved from http://carnegieendowment.org/files/CP_247_Francis_Jordan_final.pdf

Garcia, M. T. M., \& Guerreiro, J. P. S. M. (2016). Internal and external determinants of banks' profitability: The Portuguese case. Journal of Economic Studies, 43(1), 90-107. https://doi.org/10.1108/JES-09-2014-0166

Ghosh, S. (2016). Political transition and bank performance: How important was the Arab Spring?. Journal of Comparative Economics, 44(2), 372-382. https://doi.org/10.1016/j.jce.2015.02.001

Gujarati, D. N., \& Porter, D. (2008). Basic Econometrics. McGraw-Hill Irwin.

Hasan, M. S. A., Manurung, A. H., \& Usman, B. (2020, February). Determinants of Bank Profitability with Size as Moderating Variable. Journal of Applied Finance \& Banking, 10, 153-166.

Iskandar, A. S., Che-Yahya, N., \& Wahid, Z. A. (2019). Determinants of Commercial Banks' Profitability in Malaysia. Journal of Entrepreneurship and Business, 7(1), 27-39. https://doi.org/10.17687/JEB.0701.03

Jadah, H. M., Alghanimi, M. H. A., Al-Dahaan, N. S. H., \& Al-Husainy, N. H. M. (2020). Internal and external determinants of Iraqi bank profitability. Banks and Bank Systems, 15(2), 79-93. https://doi.org/10.21511/bbs.15(2).2020.08

Jara-Bertin, M., Moya, J., \& Perales, A. (2014). Determinants of Bank Performance: Evidence for Latin America. Academia Revista Latinoamericana de Administración, 27(2), 164-182. https://doi.org/10.1108/ARLA-04-2013-0030

Knezevic, A., \& Dobromirov, D. (2016). The determinants of Serbian banking industry profitability. Economic Research-Ekonomska Istraživanja, 29(1), 459-474. https://doi.org/10.1080/1331677X.2016.1174390

Marijana, Ć., Poposki, K., \& Pepur, S. (2012). Profitability Determinants of the Macedonian Banking Sector in Changing Environment. Procedia - Social and Behavioral Sciences, 44(2012), 406-416. https://doi.org/10.1016/j.sbspro.2012.05.045

Masood, O., \& Ashraf, M. (2012). Bank-specific and macroeconomic profitability determinants of Islamic banks: The case of different countries. Qualitative Research in Financial Markets, 4(3), 255-268. https://doi.org/10.1108/17554171211252565

Misra, S. D. (2015). Determinants of bank profitability in India. International Journal for Indian Culture and Business Management, 10(2), 193-211. https://doi.org/10.5296/ijafr.v5i1.7368

Mokni, R. B. S., \& Rachdi, H. (2014). Assessing the bank profitability in the MENA region. International Journal of Islamic and Middle Eastern Finance and Management, 7(3), 305-332. https://doi.org/10.1108/IMEFM-03-2013-0031

Nuhiu, A., Hoti, A., \& Bektashi, M. (2017). Determinants of commercial banks profitability through analysis of financial performance indicators: Evidence from Kosovo. Business: Theory and Practice, 18, 160-170. https://doi.org/10.3846/btp.2017.017 
Öhman, P., \& Yazdanfar, D. (2018). Organizational-level profitability determinants in commercial banks: Swedish evidence. Journal of Economic Studies, 45(6), 1175-1191.

Ozili, P. K. (2017). Bank Profitability and Capital Regulation: Evidence from Listed and non-Listed Banks in Africa. Journal of African Business, 18(2), 1-26. https://doi.org/10.1080/15228916.2017.1247329

Paolucci, G., \& Menicucci, E. (2016). The determinants of bank profitability: empirical evidence from European banking sector Article information: Users who downloaded this article also downloaded: About Emerald www.emeraldinsight.com. Journal of Financial Reporting and Accounting, 14(1), 86-115.

Pervan, M., Pelivan, I., \& Arnerić, J. (2015). Profit persistence and determinants of bank profitability in Croatia. Economic Research-Ekonomska Istraživanja, 28(1), 284-298. https://doi.org/10.1080/1331677X.2015.1041778

Petria, N., Capraru, B., \& Ihnatov, I. (2015). Determinants of banks ' profitability: evidence from EU 27 banking systems. Procedia Economics and Finance, 20(15), 518-524. https://doi.org/10.1016/S2212-5671(15)00104-5

Prasanto, O., Wulandari, D., Narmaditya, B. S., \& Kamaludin, M. (2020). Determinants of Bank Profitability: A New Evidence From State-Owned Banks In Indonesia. Trikonomika, 19(1), 29-35. https://doi.org/10.23969/trikonomika.v19i1.1443

Ramadhanti, C., Marlina, M., \& Hidayati, S. (2019). The Effect Capital Adequacy, Liquidity and Credit Risk to Profitability of Commercial Banks. Journal of Economics, Business, and Government Challenges, 2(1), 71-78. https://doi.org/https://doi.org/10.33005/ebgc.v2i1.66

Roodman, D. (2009). How to do xtabond2: An introduction to difference and system GMM in Stata. Stata Journal, 9(1), 86-136. https://doi.org/10.1177/1536867x0900900106

Rother, B., Pierre, G., Lombardo, D., Herrala, R., Toffano, P., Roos, E., \& Manasseh, K. (2016). The Economic Impact of Conflicts and the Refugee Crisis in the Middle East and North Africa.

Ruziqa, A. (2013). The impact of credit and liquidity risk on bank financial performance: the case of Indonesian Conventional Bank with total asset above 10 trillion Rupiah. International Journal of Economic Policy in Emerging Economies, 6(2), 93-106. https://doi.org/10.1504/IJEPEE.2013.055791

Samad, A. (2017). Are Bank Profits Determined by Bank-Specific Factors or Bank External Factors? Evidence from Malaysian Banks. Journal of International Business and Economics, 5(1), 1-10. https://doi.org/10.15640/jibe.v5n1a1

Saona, P. (2016). Intra- and extra-bank determinants of Latin American Banks' profitability. International Review of Economics and Finance, 45(9), 197-214. https://doi.org/10.1016/j.iref.2016.06.004

Sufian, F. (2012). Determinants of bank profitability in developing economies: empirical evidence from the South Asian banking sectors. Contemporary South Asia, 20(3), 375-399. https://doi.org/10.1080/09584935.2012.696089

Sun, P. H., Mohamad, S., \& Ariff, M. (2016). Determinants driving bank performance: A comparison of two types of banks in the OIC. Pacific Basin Finance Journal, 42(4), 193-203. https://doi.org/10.1016/j.pacfin.2016.02.007

Tan, Y., \& Floros, C. (2012a). Bank profitability and GDP growth in China: a note. Journal of Chinese Economic and Business Studies, 10(October 2013), 267-273. https://doi.org/10.1080/14765284.2012.703541

Tan, Y., \& Floros, C. (2012b). Stock market volatility and bank performance in China. Studies in Economics and Finance, 29(3), 211-228. https://doi.org/10.1108/10867371211246885

Titko, J., Skvarciany, V., \& Jurevičienè, D. (2015). Drivers of bank profitability: Case of Latvia and Lithuania. Intellectual Economics, 9(2), 120-129. https://doi.org/10.1016/j.intele.2016.02.003

Zarrouk, H., Ben Jedidia, K., \& Moualhi, M. (2016). Is Islamic bank profitability driven by same forces as conventional banks? International Journal of Islamic and Middle Eastern Finance and Management, 9(1), 4666. https://doi.org/10.1108/IMEFM-12-2014-0120

\section{Copyrights}

Copyright for this article is retained by the author(s), with first publication rights granted to the journal.

This is an open-access article distributed under the terms and conditions of the Creative Commons Attribution license (http://creativecommons.org/licenses/by/4.0/). 